\title{
MODEL KEBUTUHAN PARKIR UNTUK RUMAH SAKIT STUDI KASUS : RUMAH SAKIT BUNDA KOTA GORONTALO
}

\author{
St Maryam $\mathrm{H}^{1}$, Lambang Basri Said ${ }^{2}$, Antum Abdullah ${ }^{3}$ \\ ${ }^{1}$ Dosen, Universitas Muslim Indonesia (UMI) \\ Jalan Urip Sumoharjo No.225 Makassar, Telp. 454534 \\ ${ }^{2}$ Dosen, Universitas Muslim Indonesia (UMI) \\ Jalan Urip Sumoharjo No.225 Makassar, Telp. 454534 \\ ${ }^{3}$ Mahasiswa Magister Teknik Sipil Universitas Muslim Indonesia (UMI \\ Jalan Urip Sumoharjo No.225 Makassar, Telp. 454534, Email: kanda.daud76@gmail.com
}

\begin{abstract}
ABSTRAK
Fasilitas tempat parkir harus direncanakan dengan baik, karena kalau besar dari kebutuhan akan terjadi pemborosan, sebaliknya apabila kurang akan menimbulkan konflik pada ruas jalan sekitar rumah sakit. Pada beberapa negara telah memiliki standar kebutuhan parkir menurut fungsi tata guna tanah, demikian pula untuk kebutuhan parkir di rumah sakit, seperti di Amerika Serikat kebutuhan parkir rumah sakit berkisar antara $2-2,7$ tempat tidur per satu ruang parkir (Hunnicutt, 1967), sedangkan di India berkisar 10 tempat tidur per satu tempat parkir (Indian Road Congress, 1973). Indonesia sampai saat ini belum memiliki standar terse-but, sehingga perlu dilakukan penelitian untuk mencoba mencari model kebutuhan parkir untuk rumah sakit, khususnya di Kota Gorontalo. Penelitian ini bertujuan untuk Menganalisis Standar kebutuhan parkir pada Rumah Sakit Bunda di Gorontalo serta Menganalisis Hubungan antara jumlah ruang parkir yang dibutuhkan dengan beberapa parameter yang ada pada rumah sakit seperti jumlah tempat tidur rawat, jumlah dokter, jumlah pa-ramedis, dan jumlah pegawai. Jenis penelitian yang dilakukan bersifat deskriptif kualitatif dan kuantitatif yaitu memberikan gambaran secara tepat mengenai kondisi, Keadaan, keinginan maupun gejala yang terjadi pada masyarakat. Desain penelitian yang dilaksanakan adalah dengan metode survei atau terjun langsung ke lokasi penelitian, dengan tujuan untuk memperoleh data dan informasi yang lebih akurat dari masyarakat. Dari hasil analisis dan pembahasan maka dapat ditarik beberapa kesimpulan yakni [1] Kebutuhan fasilitas parkir untuk rumah sakit Bunda Kota Gorontalo sangat ditentukan oleh jumlah kamar rawat yang ada. [2] Model hubungan kebutuhan fasilitas parkir dengan jumlah tempat tidur rawat, kehadiran dokter, paramedic dan pegawai merupakan hubungan matematis exponensial $\mathrm{y}=1.01 \mathrm{e}^{(-13 . \mathrm{X})}$ dengan nilai $\mathrm{r}^{2}=0.894$. [3] Selain tempat tidur, parameter jumlah pegawai, jumlah paramedis, dan kehadiran dokter juga memberikan sumbangan atas keperluan parkir namun tidak sebesar tempat tidur.
\end{abstract}

Kata Kunci : model kebutuhan parkir, rumah sakit, kebutuhan parkir rumah sakit

\subsection{Latar Belakang}

\section{PENDAHULUAN}

Fasilitas parkir merupakan bagian integral dari suatu sistem transportasi. Apabila suatu perjalanan tiba pada tujuannya, kendaraan harus diparkir selama pengguna kendaraan melakukan berbagai aktivitasnya. Pengertian parkir secara sederhana adalah untuk menampung kendaraan ketika tidak dipergunakan. Kegagalan dalam penyediaan fasilitas parkir yang memadai akan menyebabkan kemacetan lalu lintas, bahkan bisa menurunkan nilai akses dari suatu bangunan.

Penyediaan fasilitas parkir untuk rumah sakit sangat penting, karena rumah sakit selalu berada pada lokasi strategis yang mudah dicapai oleh masyarakat. Pada beberapa rumah sakit banyak dijumpai kepadatan kendaraan saat akan parkir akibat lahan untuk parkir yang tidak mencukupi khususnya saat jam-jam sibuk. Sebagai alternatifnya banyak kendaraan yang parkir di tepi jalan disekitarnya yang menimbulkan masalah kemacetan lalu lintas. 
Fasilitas tempat parkir harus direncanakan dengan baik, karena kalau besar dari kebutuhan akan terjadi pemborosan, sebaliknya apabila kurang akan menimbulkan konflik pada ruas jalan sekitar rumah sakit. Pada beberapa negara telah memiliki standar kebutuhan parkir menurut fungsi tata guna tanah, demikian pula untuk kebutuhan parkir di rumah sakit, seperti di Amerika Serikat kebutuhan parkir rumah sakit berkisar antara $2-2,7$ tempat tidur per satu ruang parkir (Hunnicutt, 1967), sedangkan di India berkisar 10 tempat tidur per satu tempat parkir (Indian Road Congress, 1973). Indonesia sampai saat ini belum memiliki standar tersebut, sehingga perlu dilakukan penelitian untuk mencoba mencari model kebutuhan parkir untuk rumah sakit, khususnya di Kota Gorontalo.

\subsection{Rumusan Masalah}

Berdasarkan latar belakang di atas maka dapat dirumuskan beberapa masalah sebagai berikut :

1. Bagaimana standar kebutuhan parkir pada Rumah Sakit Bunda di Gorontalo ?

2. Bagaimana Hubungan antara jumlah ruang parkir yang dibutuhkan, dengan beberapa parameter yang ada pada rumah sakit seperti jumlah tempat tidur rawat, jumlah dokter, jumlah paramedis, dan jumlah pegawai ?

\subsection{Tujuan Penelitian}

Penelitian ini diharapkan dapat memberikan :

1. Menganalisis Standar kebutuhan parkir pada Rumah Sakit Bunda di Gorontalo.

2. Menganalisis Hubungan antara jumlah ruang parkir yang dibutuhkan dengan beberapa parameter yang ada pada rumah sakit seperti jumlah tempat tidur rawat, jumlah dokter, jumlah pa-ramedis, dan jumlah pegawai.

\section{METODOLOGI PENELITIAN}

\subsection{Jenis dan Desain Penelitian}

Jenis penelitian yang dilakukan bersifat deskriptif kualitatif dan kuantitatif yaitu memberikan gambaran secara tepat mengenai kondisi, Keadaan, keinginan maupun gejala yang terjadi pada masyarakat.

Desain penelitian yang dilaksanakan adalah dengan metode survei atau terjun langsung ke lokasi penelitian, dengan tujuan untuk memperoleh data dan informasi yang lebih akurat dari masyarakat.

\subsection{Waktu dan Lokasi Penelitian}

Penelitian ini dilakukan pada Rumah Sakit Kota Gorontalo. Waktu penelitian di laksanakan selama 2 bulan yakni mulai akhir November 2016 hingga bulan Februari 2017 sehingga data yang diperoleh selama waktu penelitian tersebut sudah lengkap dan dapat dianalisis untuk memberikan jawaban atas rumusan masalah penelitian.

2.3.Teknik Pengambilan Data

Sebelum diadakan penelitian dilakukan dahulu pra-survey pada lokasi rumah sakit yang ditinjau yaitu rumah sakit Bunda Kota Gorontalo dengan tujuan untuk mengetahui keadaan lapangan dan memudahkan dalam menyusun serta mendapatkan data-data yang dibutuhkan.

Penelitian dilanjutkan dengan menghubungi dan mewawancarai pihak pengelola rumah sakit untuk memperoleh data dan informasi tentang fasilitas rumah sakit yang dibutuhkan. Pengamatan langsung di lapangan dilaksanakan berupa perhitungan jumlah kendaraan yang parkir di rumah sakit, fluktuasi keterisian tempat tidur rawat, kehadiran dokter, paramedis dan pegawai. Pengamatan dilaksanakan pada jam 08.00 - 18.00 setiap harinya, selama seminggu pada masing-masing rumah sakit. Fluktuasi jumlah kendaraan parkir, keterisian tempat tidur rawat, kehadiran dokter, paramedis, dan pegawai, diamati selang interval 30 menit.

Pengambilan data penelitian dilakukan secara survei dan wawancara, data tersebut dapat dibedakan menjadi 2 (dua) berdasarkan sumber data, yaitu sebagai berikut : 
a. Survei Primer

Pengambilan data melalui survei volume parkir pada Rumah Sakit Bunda Kota Gorontalo. Survei dilakukan setelah mendapatkan izin dari pihak Rumah Sakit. Survei volume Parkir dilakukan selama tiga hari dengan menghitung jumlah kendaraan pada jam buka dan jam tutup Rumah Sakit Bunda Kota Gorontalo.

\section{b. Survei Sekunder}

Data Sekunder merupakan data yang dihasilkan dari survei pendahuluan, data didapatkan dari pihak Rumah Sakit yang ditinjau. Data sekunder diperlukan untuk membantu dalam kegiatan wawancara. Data sekunder adalah berupa:

- Jumlah dokter, paramedic dan pegawai pada Rumah Sakit yang ditinjau.

- Jenis penggunaan ruang, untuk mengetahui jumlah tempat tidur pada wilayah studi.

\subsection{Variabel Penelitian}

Variabel - variabel yang berpengaruh dalam perancangan model kebutuhan parker untuk rumah sakit adalah sebagai berikut :

- $\mathrm{y}=$ kebutuhan parkir,

- $\mathrm{x} 1$ = variabel tempat tidur,

- $\quad \mathrm{x} 2$ = variabel kehadiran dokter,

- $\mathrm{x} 3=$ variabel kehadiran paramedis,

- $\mathrm{x} 4$ = variabel kehadiran pegawai.

\section{HASIL DAN PEMBAHASAN}

Dalam penelitian ini, analisis data yang dilakukan menggunakan pendekatan kuantitatif yaitu dengan menggunakan analisis regresi sederhana, dan perhitungannya menggunakan program SPSS for windows versi 16 . Berikut merupakan hasil analisis dan pembahasannya.

Sebelum melakukan analisis regresi, terlebih dahulu data tingkat pengangguran dengan tingkat inflasi akan dibuat plot untuk melihat keadaan data dari variabel bebas terhadap variabel terikat sebagai berikut:

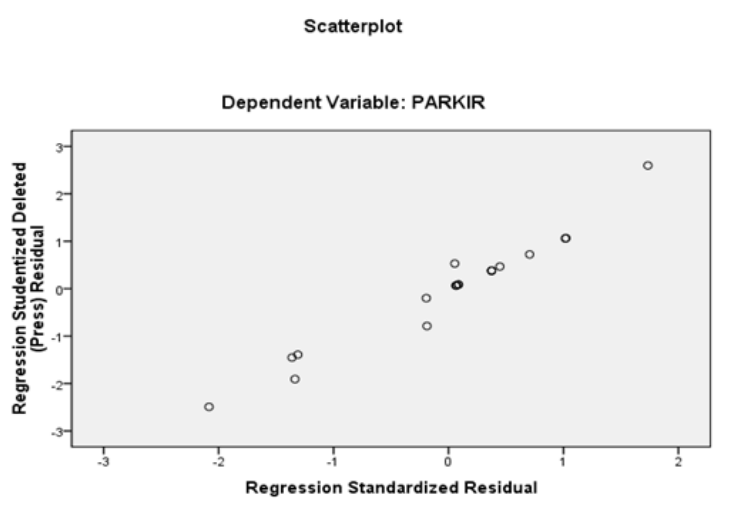

Gambar 1. Plot antara peubah X dengan Y

Berdasarkan gambar 1 dapat dibuat plot variabel bebas terhadap variable terikatnya. Dari plot yang didapat, menunjukkan data cenderung Positif, sehingga data yang dikumpulkan kemudian dapat dilakukan pengujian dengan menggunakan analisis regresi sederhana.

Berikut merupakan hasil output dengan menggunakan program SPSS, sebagai berikut: 
Tabel 1. Statistic deskriptif

Descriptive Statistics

\begin{tabular}{|l|r|r|r|}
\hline & \multicolumn{1}{|c|}{ Mean } & \multicolumn{1}{c|}{$\begin{array}{c}\text { Std. } \\
\text { Deviation }\end{array}$} & \multicolumn{1}{c|}{$\mathrm{N}$} \\
\hline PARKIR & 11.24 & 3.254 & 21 \\
RANJANG & $9.014966 \mathrm{E} 1$ & .0311740 & 21 \\
DOKTER & $3.568707 \mathrm{E} 1$ & 1.1353495 & 21 \\
PARAMEDIS & $8.845578 \mathrm{E} 1$ & 2.3472168 & 21 \\
PEGAWAI & $4.839456 \mathrm{E} 1$ & 11.5823498 & 21 \\
\hline
\end{tabular}

Tabel 2. korelasi

Correlations

\begin{tabular}{|c|c|c|c|c|c|c|}
\hline & & PARKIR & RANJANG & DOKTER & PARAMEDIS & PEGAWAI \\
\hline \multirow[t]{5}{*}{ Pearson Correlation } & PARKIR & 1.000 & .265 & .286 & .319 & .250 \\
\hline & RANJANG & .265 & 1.000 & .005 & .053 & -.237 \\
\hline & DOKTER & .286 & .005 & 1.000 & .841 & .468 \\
\hline & PARAMEDIS & .319 & .053 & .841 & 1.000 & .355 \\
\hline & PEGAWAI & .250 & -.237 & .468 & .355 & 1.000 \\
\hline \multirow[t]{5}{*}{ Sig. (1-tailed) } & PARKIR & & .123 & .104 & .079 & .138 \\
\hline & RANJANG & .123 & & .491 & .410 & .151 \\
\hline & DOKTER & .104 & .491 & & .000 & .016 \\
\hline & PARAMEDIS & .079 & .410 & .000 & & .057 \\
\hline & PEGAWAI & .138 & .151 & .016 & .057 & \\
\hline \multirow[t]{5}{*}{$\mathrm{N}$} & PARKIR & 21 & 21 & 21 & 21 & 21 \\
\hline & RANJANG & 21 & 21 & 21 & 21 & 21 \\
\hline & DOKTER & 21 & 21 & 21 & 21 & 21 \\
\hline & PARAMEDIS & 21 & 21 & 21 & 21 & 21 \\
\hline & PEGAWAI & 21 & 21 & 21 & 21 & 21 \\
\hline
\end{tabular}

Tabel 3. ANOVA

ANOVA $^{b}$

\begin{tabular}{|ll|r|r|r|r|r|}
\hline Model & & Sum of Squares & df & Mean Square & F & \multicolumn{1}{c|}{ Sig. } \\
\hline 1 & Regression & 45.177 & 4 & 11.294 & 1.084 & $.397^{\mathrm{a}}$ \\
& Residual & 166.633 & 16 & 10.415 & & \\
& Total & 211.810 & 20 & & & \\
\hline
\end{tabular}

a. Predictors: (Constant), PEGAWAI, RANJANG, PARAMEDIS,

\section{DOKTER}

b. Dependent Variable: PARKIR

Tabel 4. Variabel yang dimasukkan/dikeluarkan

Variables Entered/Removed ${ }^{\mathrm{b}}$

\begin{tabular}{|l|l|l|l|}
\hline Model & Variables Entered & $\begin{array}{l}\text { Variables } \\
\text { Removed }\end{array}$ & Method \\
\hline 1 & $\begin{array}{l}\text { PEGAWAI, } \\
\text { RANJANG, } \\
\text { PARAMEDIS, } \\
\text { DOKTER }\end{array}$ & & \\
\hline
\end{tabular}

a. All requested variables entered. 


\section{Variables Entered/Removed ${ }^{\mathrm{b}}$}

\begin{tabular}{|l|l|l|l|}
\hline Model & Variables Entered & $\begin{array}{l}\text { Variables } \\
\text { Removed }\end{array}$ & Method \\
\hline 1 & $\begin{array}{l}\text { PEGAWAI, } \\
\text { RANJANG, } \\
\text { PARAMEDIS, } \\
\text { DOKTER }\end{array}$ & & \\
& & & Enter \\
\hline
\end{tabular}

b. Dependent Variable: PARKIR

Collinearity Diagnostics ${ }^{\mathrm{a}}$

\begin{tabular}{|c|c|c|c|c|c|c|c|c|}
\hline \multirow[b]{2}{*}{ Model } & \multirow[b]{2}{*}{ Dimension } & \multirow[b]{2}{*}{ Eigenvalue } & \multirow{2}{*}{$\begin{array}{l}\text { Condition } \\
\text { Index }\end{array}$} & \multicolumn{5}{|c|}{ Variance Proportions } \\
\hline & & & & (Constant) & RANJANG & DOKTER & PARAMEDIS & PEGAWAI \\
\hline \multirow[t]{5}{*}{1} & 1 & 4.959 & 1.000 & .00 & .00 & .00 & .00 & .00 \\
\hline & 2 & .040 & 11.153 & .00 & .00 & .00 & .00 & .75 \\
\hline & 3 & .001 & 87.975 & .00 & .00 & .14 & .05 & .15 \\
\hline & 4 & .000 & 203.865 & .00 & .00 & .86 & .94 & .03 \\
\hline & 5 & $5.258 \mathrm{E}-8$ & 9711.496 & 1.00 & 1.00 & .00 & .00 & .07 \\
\hline
\end{tabular}

a. Dependent Variable: PARKIR

Tabel 5. Statistic Residual

Residuals Statistics ${ }^{\text {a }}$

\begin{tabular}{|l|r|r|r|r|r|}
\hline & Minimum & Maximum & Mean & Std. Deviation & N \\
\hline Predicted Value & 6.83 & 15.00 & 11.24 & 1.503 & 21 \\
Std. Predicted Value & -2.936 & 2.503 & .000 & 1.000 & 21 \\
Standard Error of Predicted & .789 & 3.227 & 1.335 & .856 & 21 \\
Value & -10.51 & 20.93 & 10.67 & 5.604 & 20 \\
Adjusted Predicted Value & -6.723 & 5.597 & .000 & 2.886 & 21 \\
Residual & -2.083 & 1.734 & .000 & .894 & 21 \\
Std. Residual & -2.164 & 2.227 & -.002 & 1.052 & 20 \\
\hline Stud. Residual & -10.931 & 17.511 & .377 & 6.070 & 20 \\
Deleted Residual & -2.492 & 2.596 & -.014 & 1.148 & 20 \\
Stud. Deleted Residual & .244 & 19.048 & 3.810 & 6.515 & 21 \\
Mahal. Distance & .000 & 5.830 & .465 & 1.357 & 20 \\
Cook's Distance & .012 & .952 & .190 & .326 & 21 \\
Centered Leverage Value & & & & \\
\hline
\end{tabular}

Dari hasil output dengan menggunakan program SPSS tersebut, analisis yang dihasilkan adalah:

1. Rata-rata Keterisian tempat tidur rawat adalah 0.901 dengan deviasi standar 0.031. Sedangkan rata-rata kehadiran dokter adalah 0.357 dengan deviasi standar 1.135. Sedangkan rata-rata kehadiran paramedis adalah 0.885 dengan deviasi standar 2.347. Sedangkan rata-rata kehadiran pegawai adalah 0.484 dengan deviasi standar 11.582. tingkat kebutuhan parkir adalah 11.24 dengan deviasi standar 3.254.

2. Koefisien korelasi antara ketersediaan parkir dengan kehadiran paramedic adalah sebesar 0,319 . Jadi kesimpulan yang dapat diambil adalah bahwa hubungan korelasi yang terjadi antara ketersediaan parkir dengan kehadiran paramedic adalah relatif lemah. 
3. Kolom pertama dari uji ANNOVA adalah kolom regression, yaitu jumlah kuadrat dari varians yang dihasilkan oleh model persamaan regresi, sedangkan kolom kedua adalah residual, yaitu jumlah kuadrat varians yang tidak dihasilkan dari model persamaan regresi.

4. Tabel Collinearity Diagnostics merupakan tabel untuk mendeteksi adanya multikolinearitas. jika pada analisis ini melakukan analisis regresi sederhana dimana hanya terdapat satu variabel independen, maka pendeteksian adanya gejala multikolinearitas hanya akan membuang waktu karena jumlah variable independennya hanya satu. Pada analisis ini terdapat empat variabel indipenden maka perlu dilakukan uji multikolinieritas.

5. Tabel residual statistik merupakan tabel analisis residual. Analisis residual adalah analisis untuk kesalahan dari persamaan regresi dalam memprediksi tingkat kebutuhan parkir dengan menggunakan variabel kehadiran dokter, paramedic, keterisian tempat tidur rawat dan kehadiran pegawai.

\subsection{Analisis Regresi Sederhana}

Analisis regresi sederhana digunakan untuk mengetahui pengaruh tingkat kebutuhan parkir di Rumah sakit Bunda Kota Gorontalo terhadap kehadiran dokter, paramedic, keterisian tempat tidur rawat dan kehadiran pegawai. Berikut merupakan hasil perhitungan program komputer staistik SPSS for windows versi 6:

Tabel 6. Hasil Analisis Regresi X terhadap Y

Coefficients $^{\mathrm{a}}$

\begin{tabular}{|c|c|c|c|c|c|c|c|c|c|c|c|}
\hline \multirow{2}{*}{\multicolumn{2}{|c|}{ Model }} & \multicolumn{2}{|c|}{$\begin{array}{l}\text { Unstandardized } \\
\text { Coefficients }\end{array}$} & \multirow{2}{*}{$\begin{array}{c}\begin{array}{c}\text { Standardized } \\
\text { Coefficients }\end{array} \\
\text { Beta }\end{array}$} & \multirow[b]{2}{*}{$\mathrm{t}$} & \multirow[b]{2}{*}{ Sig. } & \multicolumn{3}{|c|}{ Correlations } & \multicolumn{2}{|c|}{ Collinearity Statistics } \\
\hline & & B & Std. Error & & & & Zero-order & Partial & Part & Tolerance & VIF \\
\hline \multirow[t]{5}{*}{1} & (Constant) & -2959.234 & 2169.890 & & -1.364 & .192 & & & & & \\
\hline & RANJANG & 32.624 & 24.108 & .313 & 1.353 & .195 & .265 & .320 & .300 & .922 & 1.085 \\
\hline & DOKTER & -.131 & 1.248 & -.046 & -.105 & .917 & .286 & -.026 & -.023 & .259 & 3.854 \\
\hline & PARAMEDIS & .346 & .572 & .250 & .606 & .553 & .319 & .150 & .134 & .289 & 3.459 \\
\hline & PEGAWAI & .072 & .073 & .256 & .981 & .341 & .250 & .238 & .218 & .721 & 1.387 \\
\hline
\end{tabular}

Setelah mengetahui hasil output dari SPSS for windows versi 16, langkah berikutnya adalah membentuk persamaan yang sesuai dalam rumusan persamaan regresi sederhana dimana:

$$
\mathrm{Y}=\mathrm{a}+\mathrm{bX}
$$

Kemudian, dari rumusan persamaan tersebut dan berdasarkan pada tabel 14, dapat diketahui persamaan regresinya adalah:

$$
\mathrm{Y}=-2959.234+\mathbf{3 2 . 6 2 4} \mathrm{X}_{1}+(-0.131) \mathrm{X}_{2}+0.346 \mathrm{X}_{3}+0.072 \mathrm{X}_{4}
$$

Dari persamaan tersebut, dapat dirumuskan bahwa

1. nilai bilangan konstanta (a) adalah -2959.234 dan nilai koefisien regresinya adalah 32.624. Nilai konstanta (a) yang sebesar -2959.234 memberikan indikasi bahwa nilai rata-rata tingkat ketersediaan parker di rumah sakit bunda adalah sebesar -2959.234 satuan pada saat nilai prediktor (X1) sama dengan nol (0). Kemudian, untuk nilai koefisien prediktor tingkat keterisian tempat tidur rawat (b) yang sebesar 32,624 memberikan indikasi bahwa apabila terjadi perubahan prediktor tingkat keterisian tempat tidur rawat $\left(\mathrm{X}_{1}\right)$ sebesar satu satuan, menyebabkan perubahan rata-rata tingkat kebutuhan parkir (Y) di rumah sakit bunda kota gorontalo sebesar 32,624 satuan.

2. untuk nilai koefisien prediktor tingkat kehadiran dokter (b) yang sebesar -0,131 memberikan indikasi bahwa apabila terjadi perubahan prediktor tingkat kehadiran dokter $\left(\mathrm{X}_{2}\right)$ sebesar satu satuan, menyebabkan perubahan rata-rata tingkat ketersediaan parkir (Y) di rumah sakit bunda kota gorontalo sebesar -0,131 satuan.

3. untuk nilai koefisien prediktor tingkat kehadiran paramedis (b) yang sebesar 0,346 memberikan indikasi bahwa apabila terjadi perubahan prediktor tingkat kehadiran 
paramedis $\left(\mathrm{X}_{3}\right)$ sebesar satu satuan, menyebabkan perubahan rata-rata tingkat ketersediaan parkir (Y) di rumah sakit bunda kota gorontalo sebesar 0,346 satuan.

4. untuk nilai koefisien prediktor tingkat kehadiran pegawai (b) yang sebesar 0,072 memberikan indikasi bahwa apabila terjadi perubahan prediktor tingkat kehadiran pegawai $\left(\mathrm{X}_{4}\right)$ sebesar satu satuan, menyebabkan perubahan rata-rata tingkat ketersediaan parkir (Y) di rumah sakit bunda kota gorontalo sebesar 0,072 satuan.

Selanjutnya melihat hubungan variabel bebas dan variabel terikat. Untuk mencari hubungan kedua variabel tersebut, maka langkah yang ditempuh adalah melakukan pengujian analisis korelasi antara variabel $\mathrm{X}$ dan variabel $\mathrm{Y}$.

Tabel 7 Koefisien Korelasi

Model Summary ${ }^{\mathrm{b}}$

\begin{tabular}{|c|c|c|c|c|c|c|c|c|c|c|}
\hline \multirow[b]{2}{*}{ Model } & \multirow[b]{2}{*}{$\mathrm{R}$} & \multirow[b]{2}{*}{$\begin{array}{c}\mathrm{R} \\
\text { Square }\end{array}$} & \multirow[b]{2}{*}{$\begin{array}{c}\text { Adjusted R } \\
\text { Square }\end{array}$} & \multirow{2}{*}{$\begin{array}{l}\text { Std. Error } \\
\text { of the } \\
\text { Estimate }\end{array}$} & \multicolumn{5}{|c|}{ Change Statistics } & \multirow[b]{2}{*}{$\begin{array}{l}\text { Durbin- } \\
\text { Watson }\end{array}$} \\
\hline & & & & & $\begin{array}{c}\text { R Square } \\
\text { Change }\end{array}$ & $\begin{array}{c}\mathrm{F} \\
\text { Change }\end{array}$ & df1 & $\mathrm{df} 2$ & $\begin{array}{c}\text { Sig. F } \\
\text { Change }\end{array}$ & \\
\hline 1 & $.462^{\mathrm{a}}$ & .213 & .017 & 3.227 & .213 & 1.084 & 4 & 16 & .397 & 1.602 \\
\hline
\end{tabular}

a. Predictors: (Constant), PEGAWAI, RANJANG, PARAMEDIS, DOKTER

b. Dependent Variable: PARKIR

Dari tabel model summary terlihat bahwa koefisien korelasi adalah sebesar 0,462, dan koefisien determinasi adalah sebesar 0,213. Untuk melihat signifikansi koefisien determinasi kita dapat membandingkan nilai $\mathrm{F}_{\text {hitung }}$ yang sebesar 1,084 dengan nilai $\mathrm{F}_{\text {tabel, }}$ dan membandingkan antara nilai Sig dengan alpha $(1 \%)$. Nilai $F_{\text {tabel }}$ diperoleh dengan mencari pada tabel $\mathrm{F}$ dengan $\mathrm{v} 1=4$ dan $\mathrm{v} 2=16$, diperoleh nilai $\mathrm{F}_{\text {tabel }} 4,77$. Dengan nilai $\mathrm{F}_{\text {hitung }}$ sebesar 1,084 yang lebih kecil dari $\mathrm{F}_{\text {tabel }}$ yaitu 4,77 dan nilai Sig yang lebih besar dari pada alpha, maka kesimpulan yang dapat diambil adalah menolak Ha yang berarti koefisien determinasi adalah signifikan secara statistik.

Kemudian, untuk membuktikan apakah korelasi antara kelima variabel signifikan atau variabel bebas yang dapat berpengaruh terhadap variabel terikatnya, maka dilakukan uji hipotesis. Sesuai dengan pernyataan yang telah dinyatakan pada bab sebelumnya, untuk melakukan uji hipotesis, langkah yang harus ditempuh adalah dengan membandingkan $t_{\text {hitung }}$ dan $t_{\text {tabel }}$ sebagai pengujiannya.

Dari output SPSS for windows versi 16 yang diperoleh pada tabel diatas didapatkan :

1. nilai $t_{\text {hitung }}$ adalah 1,353 . Selanjutnya, $t_{\text {hitung }}$ dibandingkan dengan $t$-tabel pada tingkat signifikansi $99 \%$ atau $\alpha=0,01$, maka diperoleh nilai $t_{\text {tabel }}$ adalah 2,583 (lihat tabel $\mathrm{t}$ pada lampiran). Karena didapatkan nilai $\mathrm{t}_{\text {hitung }}<\mathrm{t}_{\text {tabel, }}$, maka $\mathrm{H} 0$ diterima dan Ha ditolak, sehingga dinyatakan terdapat pengaruh antara variabel bebas tingkat ketersediaan parkir dengan variabel terikat keterisian tempat tidur rawat.

2. nilai thitung adalah 0,105 . Selanjutnya, $t_{\text {hitung }}$ dibandingkan dengan $t$-tabel pada tingkat signifikansi $99 \%$ atau $\alpha=0,01$, maka diperoleh nilai $t_{\text {tabel }}$ adalah 2,583 (lihat tabel $\mathrm{t}$ pada lampiran). Karena didapatkan nilai $\mathrm{t}_{\text {hitung }}<\mathrm{t}_{\text {tabel, }}$, maka $\mathrm{H} 0$ diterima dan Ha ditolak, sehingga dinyatakan terdapat pengaruh antara variabel bebas tingkat ketersediaan parkir dengan variabel terikat kehadiran Dokter.

3. nilai $\mathrm{t}_{\text {hitung }}$ adalah 0,606 . Selanjutnya, $\mathrm{t}_{\text {hitung }}$ dibandingkan dengan $\mathrm{t}$-tabel pada tingkat signifikansi $99 \%$ atau $\alpha=0,01$, maka diperoleh nilai $\mathrm{t}_{\text {tabel }}$ adalah 2,583 (lihat tabel $\mathrm{t}$ pada lampiran). Karena didapatkan nilai $\mathrm{t}_{\text {hitung }}<\mathrm{t}_{\text {tabel, }}$, maka $\mathrm{H} 0$ diterima dan Ha ditolak, sehingga dinyatakan terdapat pengaruh antara variabel bebas tingkat ketersediaan parkir dengan variabel terikat kehadiran Paramedis.

4. nilai $t_{\text {hitung }}$ adalah 0,981 . Selanjutnya, $t_{\text {hitung }}$ dibandingkan dengan $t$-tabel pada tingkat signifikansi 99\% atau $\alpha=0,01$, maka diperoleh nilai $\mathrm{t}_{\text {tabel }}$ adalah 2,583 (lihat tabel $\mathrm{t}$ pada lampiran). Karena didapatkan nilai $\mathrm{t}_{\text {hitung }}<\mathrm{t}_{\text {tabel, }}$, maka $\mathrm{H} 0$ diterima dan Ha ditolak, 
sehingga dinyatakan terdapat pengaruh antara variabel bebas tingkat ketersediaan parkir dengan variabel terikat kehadiran pegawai.

\subsection{Uji Asumsi Klasik Normalitas}

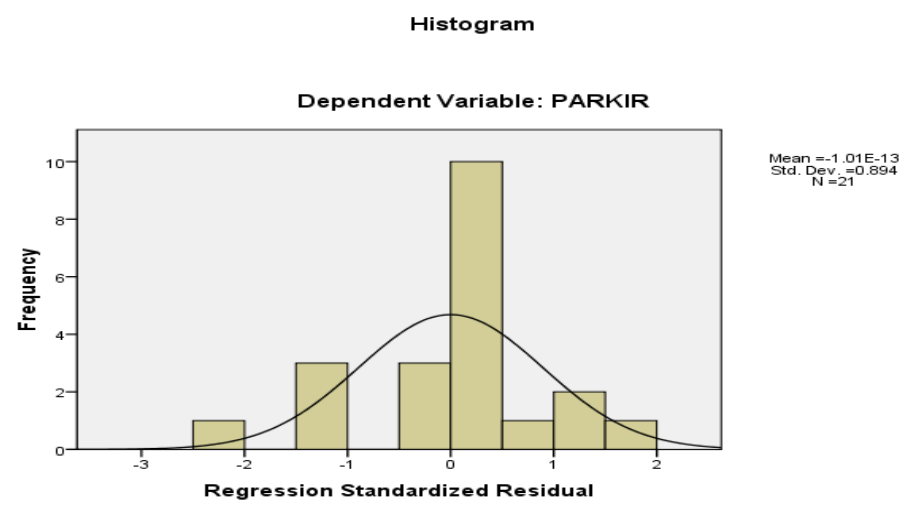

Gambar 2. Grafik Histogram

Normal P-P Plot of Regression Standardized Residual

Dependent Variable: PARKIR

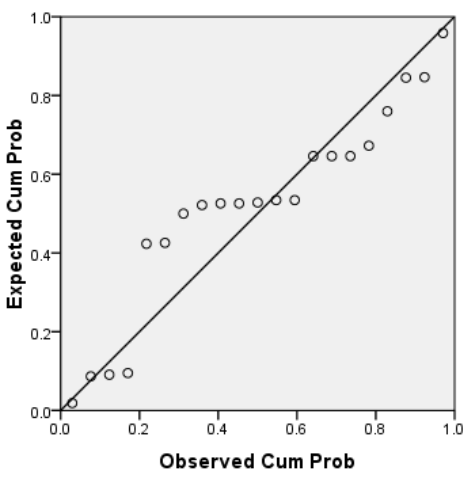

Gambar 3. Grafik Normal PP Plot

Uji asumsi klasik normalitas dipergunakan untuk menguji data variabel bebas (X) dan variabel terikat $(\mathrm{Y})$ pada persamaan regresi yang dihasilkan. Berdistribusi normal atau berdistribusi tidak normal. Persamaan regresi dikatakan baik jika memenuhi data variabel bebas dan data veriabel terikat berdistribusi mendekati normal atau normal sama sekali.

Gambar 3 adalah grafik histogram. Grafik ini menggambarkan distribusi frekuensi dari tingkat inflasi dibandingkan dengan grafik distribusi normal. Gambar 18 adalah grafik PP plots. Grafik ini menggambarkan distribusi frekuensi dari tingkat inflasi, dibandingkan dengan distribusi frekuensi yang telah ditentukan. Jika titik-titik distribusi berada disekitar garis lurus maka distribusi frekuensi pengamatan sama dengan distribusi uji yang berarti data terdistribusi secara normal. Dari grafik terlihat titik-titik distribusi terletak di sekitar garis lurus, sehingga dapat disimpulkan bahwa distribusi frekuensi tingkat inflasi sesuai dengan distribusi uji. Dengan kondisi demikian maka kesimpulan yang diperoleh adalah bahwa penyebaran tingkat inflasi mengikuti distribusi normal. 


\subsection{Uji Asumsi Klasik Autokorelasi}

Persamaan regresi yang baik adalah yang tidak memiliki masalah autokorelasi, jika terjadi autokorelasi maka persamaan tersebut menjadi tidak baik/tidak layak dipakai prediksi. Salah satu ukuran dalam menentukan ada tidaknya masalah autokorelasi dengan mendeteksi nilai Durbin Watson (DW), dengan aturan keputusannya adalah:

a. Terjadi autokorelasi positif, jika nilai DW di bawah $-2(\mathrm{DW}<-2)$

b. Tidak terjadi gejala auto-korelasi, jika nilai DW berada di antara -2 dan +2 atau $-2 \leq$ $\mathrm{DW} \leq+2$

c. Terjadi gejala autokorelasi negatif jika nilai DW di atas +2 atau DW $>+2$

Pada tabel 15 ditemukan nilai $\mathrm{DW}=2,499$. Nilai $\mathrm{DW}=1,602$ termasuk atau berada di antara -2 dan +2 atau $-2 \leq \mathrm{DW} \leq+2$ yang berarti bahwa data di atas Tidak terjadi gejala autokorelasi. Maka persamaan tersebut layak dipakai sebagai prediksi.

\section{KESIMPULAN}

Dari hasil analisis dan pembahasan maka dapat ditarik beberapa kesimpulan;

1. Kebutuhan fasilitas parkir untuk rumah sakit Bunda Kota Gorontalo sangat ditentukan oleh jumlah kamar rawat yang ada.

2. Model hubungan kebutuhan fasilitas parkir dengan jumlah tempat tidur rawat, kehadiran dokter, paramedic dan pegawai merupakan hubungan matematis exponensial $y=1.01 \mathrm{e}^{(-13 . x)}$ dengan nilai $\mathrm{r}^{2}=0.894$

3. Selain tempat tidur, parameter jumlah pegawai, jumlah paramedis, dan kehadiran dokter juga memberikan sumbangan atas keperluan parkir namun tidak sebesar tempat tidur.

\section{SARAN}

1. Perlu dilakukan penelitian yang lebih luas dengan meninjau seluruh rumah sakit yang ada di Kota Gorontalo, untuk mendapatkan hasil yang lebih akurat.

2. Perlu dilakukan tinjauan terhadap parameter lainnya misalnya pengunjung poliklinik, konsentrasi jam sibuk kunjungan pasien, dan lainnya.

3. Mahasiswa yang akan melakukan penelitan yang sama sebaiknya focus pada keterkaitan antara kebutuhan parkir terhadap jumlah pasien rawat inap serta sebaiknya focus ke beberapa rumah sakit terkait misalnya antara rumah sakit bunda Kota Gorontalo dengan Rumah Sakit Siloam Kota Gorontalo. Hal ini dimaksudkan untuk menemukan lebih mendalam tentang model kebutuhan parkir untuk rumah sakit.

\section{UCAPAN TERIMA KASIH}

Penulis mengucapkan terima kasih kepada Rekan-rekan Dinas Pekerjaan Umum Kota Gorontalo Kabupaten Gorontalo yang telah memberi dukungan financial terhadap penelitian ini. Serta terima kasih banyak kepada Dr. Ir. Hj St Maryam H.,MT dan Ir. H. Lambang Basri Said.,MT.,Ph.D selaku Ketua Pembimbing dan Anggota Pembimbing yang telah banyak memberi masukan serta arahan demi Penelitian ini.

\section{DAFTAR PUSTAKA}

1998, "Pedoman Perencanaan dan Pengoperasian Fasilitas Parkir", Jakarta, Direktorat Jenderal Perhubungan Darat.

1999, “Rekayasa Lalu Lintas”, Jakarta, Direktorat Bina Sistem Lalu Lintas

Dan Angkutan Kota Direktorat Jenderal Perhubungan Darat.

Alamsyah, Ansyori A, “Rekayasa Lalu-Lintas”, UMM Press, Malang, 2005. 
Anonymous, 1993 "Indonesian High Capacity Manual, Part I : Urban Roads", Directorat General of Highways Ministry Of Public Works, Jakarta.

Aviasti, “Jurnal TMI”, Fakultas Teknik, Penerbit UNISBA, 2004

Dajan, Anto (1978), Pengantar Metode Statistik Jilid 1 dan 2, LP3ES, Jakarta.

Edwarsyah,M, "Usulan Tata Letak Fasilitas Parkir Kendaraan Bermotor di UPN Veteran", Jakarta, 2008.

Flaherty,C.A. (1974), Highway and Traffic volume 1, Institute for Transport Studies, Leeds.

Hobbs, F.D. (1995), Perencanaan dan Teknik Lalu Lintas, Edisi kedua, terjemahan oleh Suprapto TM, Universitas Gadjah Mada, Yogyakarta.

Hunnicutt, J. M. (1967), Parking Loading and Terminal Facilities, Hunnicutt and Associates, Inc., Washington DC.

Khisty, Jotin, C. and Lall, B.K. (1998), Transportation Engineering An Introduction, Second Edition, New Jersey.

Nasution, S, “Metode Research Penelitian Ilmiah”, Penerbit Bumi Aksara, Jakarta, 2003.

Suryabrata, sumadi, "Metodologi Penelitian", CV.Rajawali, Jakarta, 1983.

Taju, Donny R.J. (1996), Karakteristik Kebutuhan Parkir Pada Rumah Sakit di Bandung, Tesis Program Pasca Sarjana, Institut Teknologi Bandung.

Tamin Z Ofyar. Perencanaan dan Pemodelan Transportasi, ITB Bandung, 2000.

Usman, Husaini dan Akbar, Purnomo S. (2000), Pengantar Statistika, Bumi Aksara, Jakarta. 